\title{
Gendered Experiences of Appearance-related Perks and Penalties in Finnish Labor Markets'
}

\section{I lida Kukkonen²}

Doctoral candidate, University of Turku, Unit of Economic Sociology, Finland

\section{Outi Sarpila}

Senior research fellow, University of Turku, INVEST flagship, Finland

\begin{abstract}
Physical appearance is generally associated with considerable labor-market sanctions, and appearances are thought to be of particular importance in the feminine service sector. However, little is known about workers' experiences of appearance-based perks and penalties in Nordic labor markets. Drawing on literature on aesthetic capital and labor, this study aims to fill this research gap. The study uses a nationally representative survey $(N=1600)$ fielded in Finland and multinomial regression to determine whether subjective experiences of appearance-related perks and penalties are gendered, dependent on the field of work or daily work on appearances. Our main finding is that while both men and women experience looks-based perks and penalties, men are more likely to have experienced appearance having a say in salary negotiations. Our results shed light on the gendered logics of aesthetic capital and labor, and question economic understandings of beauty work as a pathway to labor market success for women.
\end{abstract}

\section{KEYWORDS}

Aesthetic labor / aesthetic capital / appearance-based discrimination / beauty work / gender / physical attractiveness

\section{Introduction}

'Women took on all at once the roles of professional housewife, professional careerist, and professional beauty'

$$
\text { - Naomi Wolf } 2002 \text { (1991), p. } 27
$$

eminist author Naomi Wolf claimed that when the second shift (Hochschild \& Machung 2012) no longer wears women down and hinders them from gaining social and economic power, patriarchy must sustain itself by imposing beauty pressures upon women (Wolf 2002). She posited that as women gain access to and power within labor markets, they are called upon to engage in a third shift, which entails facing up to the norm of looking beautiful, especially for work (ibid.). Now, as sociologists have increasingly turned to studying physical appearance as a source of socioeconomic inequality (Anderson et al. 2010) and looks as a feminine requirement in various occupations (Mears 2014), Wolf's analysis appears once again relevant. While beauty

\footnotetext{
${ }^{1}$ You can find this text and its DOI at https://tidsskrift.dk/njwls/index.

${ }^{2}$ Corresponding author: iltkuk@utu.fi. Department of Social Research, Unit of Economic Sociology, 20014 University of Turku, Finland.
} 
is increasingly framed as a feminine asset (Gill 2007), research on appearance-related inequality does not, in fact, conclude that women benefit more from their looks than men do (for reviews, see Hosoda et al. 2003; Maestripieri et al. 2017). The analysis seems to apply to the context of a Nordic welfare state as well, as recent Finnish research shows that men and women are expected to behave differently in terms of their physical appearance. Compared to men, women are generally more approved of in cultivating their physical appearance, but less approved of in taking economic advantage of it (Sarpila et al. 2020.)

Nordic welfare states, such as Finland, which this study focuses on, have been lauded for being gender equal and occupy the highest ranks in gender equality indices (e.g., World Economic Forum 2020). Considered pioneers in 'women-friendly policies', their institutions have undoubtedly ushered men to take part in the second shift and helped women gain access to working life (Borchorst \& Siim 2002; Hernes 1987; Lister 2009). However, recent analyses considering the 'women-friendliness' of Nordic welfare states have also pointed out that in Nordic labor markets, both vertical and horizontal gender segregation loom large (Grönlund et al. 2017) and that focusing on gender equality alone risks blurring important distinctions and inequalities within gender categories (Lister 2009). Such distinctions include, importantly, ethnicity and class (Siim \& Skjeie 2008); however, relatedly, they may also touch on physical appearance.

In sociology, such appearance-based inequalities have recently been addressed using the metaphor of aesthetic capital. Aesthetic capital refers to a combination of different resources or assets related to physical appearance (including facial beauty, body shape, size and physique, styles of grooming, and clothing), and is exchangeable for other forms of capital (e.g., Anderson et al. 2010; Holla \& Kuipers 2015; Kukkonen et al. 2018; Sarpila et al. 2020). Moreover, in the past two decades, scholars over and beyond sociology-including those from organization and working life studies have considered how many employees in contemporary service economies do their best to live up to certain types of aesthetic dispositions and engage in the aesthetic labor that employers expect from them (e.g., Boyle \& De Keere 2019; Mears, 2014; Warhurst \& Nickson 2001). In many analyses of aesthetic labor, such work refers chiefly to feminine work in the service sector (e.g., Elias et al. 2017). Little is known about the wider experiences of attractiveness-related working life sanctions, that is, perks and penalties.

Our study approaches gendered labor market (dis)advantages in Nordic welfare state from a perspective that has received insufficient attention in the Nordic working life context. At the societal level, the topic is important as it concerns a form of inequality that, according to certain signs, appears to be on the rise (Sarpila et al. 2017). Crucially, previous research shows that physical appearance-related inequalities intertwine with gender.

This paper draws on literature on aesthetic capital and aesthetic labor, and addresses three research questions. First, do men and women equally experience appearancerelated sanctions (i.e., perks and penalties) in working life? Second, are such potentially gendered experiences of sanctions equally common in service industries as in other fields of work? And third, are the potentially gendered experiences of such sanctions dependent on daily beauty work? This study will engage in these questions by analyzing a nationally representative survey of Finnish-speaking Finns ( $N=1600)$.

The remainder of this paper is organized as follows. We first discuss appearancerelated discrimination in Nordic labor markets. We will then review literature on 
aesthetic capital and discuss how such capital might be gendered and field specific and introduce literature on aesthetic labor, working to intertwine these literatures. Next, we introduce tour data and methods. This section will be followed by a presentation of descriptive results, after which we present the results of our analyses. Finally, we discuss the implications of our results and conclude our study.

\section{Appearance-related discrimination in Nordic labor markets}

A plethora of quantitative studies in fields, including economics and sociology, agree that attractive people are rewarded for their looks in working life (for reviews, see Hamermesh 2011; Hosoda et al. 2003). The majority of previous research on physical appearance and working life outcomes has, however, been conducted in Anglo-Saxon countries. Yet, there is no reason to assume that physical appearance would not be a source of inequality in Nordic countries. Previous quantitative studies based on Nordic data show that physical attractiveness is associated with electoral success (Berggren et al. 2017; Laustsen 2014) and job interview call-back (Rooth 2009). Further, body mass index (BMI) is associated with income and employment status (e.g., Härkönen et al. 2011). Certain comparative studies found that the association between BMI and working-life penalties might be even more substantial in the Nordic countries than in other European countries (Villar \& Quintana-Domeque 2009).

These perks and penalties suggest the prevalence of appearance-based discrimination in Nordic labor markets. Discrimination means unequal treatment (i.e., a sanction) on the basis of a certain characteristic-in this case, physical appearance-related traits. Scholars have often referred to discrimination on the basis of physical appearance as 'lookism'. While this term has mostly been used to describe discriminatory practices that have to do with attractiveness; that is, which reward the attractive and punish the 'homely' (Hamermesh 2011), it can also be used in reference to discrimination on the basis of any visual trait considered unfavorable in a particular environment (Berry 2008).

This tendency to reward or punish, that is, sanction (prospective) workers becomes obvious in Finnish studies on embodiment in recruitment and 'headhunting'. For example, Meriläinen et al. (2015) have demonstrated how executive search practices define 'ideal' bodies and disadvantage bodies that do not fit that ideal. Similarly, Kinnunen and Parviainen (2016) have shown how physical appearance is a wellconcealed selection criterion in Finnish working life, and how it may intertwine with other 'hidden' recruitment criteria, such as age and gender.

How concealed or hidden are such discriminatory recruitment practices in the Nordic countries? Results from the Eurobarometer suggest that Europeans are well aware of the fact that workplace discrimination on the basis of 'general physical appearance (size, weight, face)' as well as 'look, manner of dress, or presentation' exist in recruitment practices. In fact, Europeans deem such lookism substantially more common than gender-based discrimination. In the Nordic EU countries (Denmark, Sweden, and Finland), perceived discrimination on the basis of physical appearance and 'looks' is significantly more common than the EU average. In all the three countries, at least half of the population deems 'general physical appearance' may affect recruitment practices. Discrimination on the basis of 'looks' is considered even slightly more widespread 
(Eurobarometer 2019). It is possible that people living in Nordic countries are more prone to acknowledging appearance-related discrimination, as it violates the equal opportunity norm, widely shared in Nordic countries. Moreover, these results indicate that appearance-related discrimination goes beyond bodily traits, such as weight, and indeed concerns aesthetic work on the self in terms of grooming.

\section{Aesthetic capital and labor}

\section{Aesthetic capital: Physical appearance as a resource}

During the past decade, sociologists have sought to utilize and develop Bourdieu's theory of capitals $(1984,1986)$ in order to understand appearance-related inequalities (see, e.g., Anderson et al. 2010 on aesthetic capital; Martin \& George 2006; Green 2014 on sexual capital; Mears 2015a, 2015b on bodily capital and girl capital). While Bourdieu highlighted the body as the locus of inequality, he did not regard the body and its appearance as a distinct form of capital comparable to economic, social, and cultural capital. ${ }^{1}$ With recent research in sociology and economics, it has, however, become established that appearance-based inequalities cannot be pinned down on economic, social, or cultural capital alone. Instead, recent empirical and theoretical scholarship suggests that appearances have their own unequalizing power: appearance constitutes a distinct form of capital that can be accumulated and exchanged. (Edmonds \& Mears 2017.)

The theory, or metaphor of capital (Skeggs 2004), suggests that aesthetic capital accumulates just like other forms of capital. That is, through labor (Bourdieu 1986). In consumerist societies, the labor of accumulating aesthetic capital happens largely through consumption. Consumption, of course, means more than acts of purchasing: it is more about the practices, or indeed labor - of consumption (Sarpila \& Åberg 2019; Warde 2005). Importantly, successfully accumulating aesthetic capital requires more than economic capital: the embodied knowledge of what counts as the 'right' looks in different circles or fields (Kuipers 2015) and mastering the skill to practice consumption 'right' (cf. Luna 2019) matter. Hence, the accumulation of aesthetic capital can occur as an exchange from economic, social, and cultural capital. Thereafter, aesthetic capital can again be exchanged for economic, social, and cultural capital. In this line of thinking, working life appears to be a particularly important field of exchanging aesthetic capital for economic capital.

Physical appearance has been considered a feminine source of power throughout the history of Western capitalism (Berry 2008), and discourses of beauty as a feminine asset have arguably been amplified in recent times (Gill 2017). However, there is in fact no scientific consensus on whether appearance actually matters more for women than it does for men. Results from quantitative research on the (socio-)economic (dis)advantages of physical appearances are actually quite ambivalent as to whether women actually profit more from looks than men do (for reviews, see Hosoda et al. 2003; Maestripieri et al. 2017).

According to an economist approach, an individual's physical appearance has a market value defined by the laws of supply and demand. A rational individual, thus, invests in their looks to maximize the profit that beauty brings, i.e. 'beauty perks'. Whether investing in one's looks actually confers 'beauty perks' is, however, unclear.

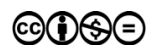


Hamermesh, Meng and Zhang (2002) found that while women's spending on beauty products and services increased women's earnings, the increase in income only partially covered this spending. Robins, Homer, and French (2011) find that being well groomed affects wages and taking grooming into account helps explain the relationship between attractiveness and income. Wong and Penner (2016), too, find that the relationship between attractiveness and income depends on grooming, but the effect is different for men and women: for women, grooming accounts for the whole 'beauty premium' whereas for men, it accounts for roughly half. Further, Das and De Loach (2011) found that the effect of grooming on earnings differs significantly by gender and race. Overall, it is somewhat doubtful that 'beauty perks' can be straightforwardly achieved by 'investing' in one's appearance (even if one has the means such investments require).

From the perspective of economic sociology, it is clear that exchange does not happen according to simple economic rules of demand and supply but is always normatively restricted (Swedberg 2003). The norms that guide the accumulation and exchange of capital may be different on the basis of (assigned) group membership, for example, different for minority and non-minority, different for women and men. Indeed, Sarpila et al. (2020) find that while Finnish women are expected to develop their aesthetic capital through appearance-related practices much more than men, exchanging such capital to economic capital in the labor market is judged more harshly for women than men: women should work on looking good, but should not try to exploit their looks at work. In contrast, men have more freedom to make use of their aesthetic capital in labor markets. Paradoxically, men also have more restrictions imposed on them when it comes to freedom to express themselves and their power through appearance and style (see also Bolsø \& Mühleisen 2017). As Neumann points out, women are at the same time pushed to invest heavily in their beauty but also shamed or ridiculed for doing so (Neumann 2017). Hence, women are not necessarily socially (or economically) rewarded for investing in their aesthetic capital. Indeed, an important question concerns who is allowed to benefit from capital (Skeggs 2004), and to put the question in different terms: whom does capital actually benefit? As Wacquant's research suggests, bodily capital can indeed be appropriated (1995). Mears' (2015a) ethnographic study in the very important person (VIP) party circuit suggests that men are more able to reap the benefits of female escorts' bodily capital than the women themselves.

The recent literature on aesthetic capital has also emphasized that the value of appearance-related capital depends on context (e.g., Holla \& Kuipers 2015; Mears 2014). Here, the concept of aesthetic labor is useful. Next, we discuss the potential of this concept for understanding the dynamics of appearance-related perks and penalties.

\section{Aesthetic labor: the requirements of looking 'right'}

The concept of aesthetic labor was coined in the early 2000s by scholars who studied new forms of labor in the Glasgow service economy (Warhurst \& Nickson 2001) to denote the labor of 'looking good and sounding right' - at and for work. In the ever more ubiquitous interactive service jobs, profit is generated through the interpersonal communication of a customer and a server, and here appearances play a key role (Williams \& Connell 2010). As the physical attributes of the service provider become part of what is exchanged in service labor markets (McDowell 2009), it is in service 
sector employers' interests to select, manage, and cultivate worker aesthetics to apply to consumer tastes (Mears 2014).

Indeed, it has been suggested that beyond the explicitly aesthetic industries revolving around fashion and beauty (e.g., Boyle \& De Keere 2019; Entwistle \& Wissinger 2006; Pettinger 2004), appearances matter most in interactive service industries that rely on returning customers (McDowell 2009). However, Nordic scholars have pointed out that this may not always be the case. Dahl (2013) criticizes the scholarship on aesthetic labor for focusing overwhelmingly on service work in the private sector, and finds in her work that aesthetic labor is a crucial part of public parking patrolling, where obviously, the aim of labor is precisely not having customers return. Huzell and Larsson (2011) make the case that employers demand aesthetic labor from employees not just in order to draw in customers, but also to avoid costs. For employers and managers, a fit and 'healthy-looking' body may serve as a proxy for reductions in sickness leave costs (ibid.).

Therefore, while aesthetic labor is considered notably a phenomenon of the interactive services, its reach is not necessarily limited to the services (Witz et al. 2003). Indeed, the concept of aesthetic labor has proven useful in studies beyond the service sector, such as in the study of creative industries (Hracs \& Leslie 2014), where aesthetics provide a way of communicating one's cultural competence and authenticity (Van den Berg \& Vonk 2019). Overall, what appears to unite the fields of work that scholarship on aesthetic labor has focused on is femininity and precariousness. Van den Berg and Arts (2019) suggest that the new ways reinforcing the importance of aesthetics in contemporary labor markets are not only due to the increase in interactive service jobs, but also the discontinuity and precarity of work. For people in precarious post-fordist labor markets, aesthetic labor may be a constant demand regardless of current employment status.

Indeed, Elias, Gill, and Scarff (2017) suggest that in neoliberalism, where 'entrepreneurship of the self' is increasingly required, the idea of aesthetic labor can be applied beyond certain fields in working life, and instead considered as a process that has relevance across social life (Elias et al. 2017). Aesthetic labor becomes mundane, as the product of the labor is an aesthetic self that needs to be 'always on' (Entwistle \& Wissinger 2006) and 'constantly calibrated' (Van Den Berg \& Arts 2019) to be mobilized for commercial gain (Adamson \& Salmenniemi 2018). In such use, the concept of aesthetic labor treads the blurry lines between waged and unwaged labor, and bleeds into body and beauty work (for a review, see Mears 2014). Indeed crucially, aesthetic labor relies on the gendered consumption practices of workers (Pettinger 2008). Such an extension of the concept brings gender back into focus: after all, it is chiefly women who engage in the unpaid 'third shift' of beauty work (Wolf 2002).

Scholars have argued that the neoliberal culture is gendered, and it is in particular women as its 'ideal subjects', who are called upon to constantly reinvent themselves (Elias et al. 2017; McRobbie 2009). The demands made on the female body have not only intensified, but also extended across the lifespan and onto new areas of the female body (Gill 2017). While female beauty practices and work on the self are increasingly framed as empowering and joyful choices (Gill 2017; McRobbie 2009), fact remains women are normatively called upon and expected to engage in such unpaid labor, even in seemingly 'women-friendly' societies such as Finland (Sarpila et al. 2020). The question of whether this beauty work, or lack thereof, is sanctioned (i.e., rewarded or penalized) remains unanswered.

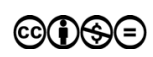




\section{Data and methods}

\section{Data}

In order to examine how appearance-related working life sanctions on the Finnish labor market are dependent on gender, occupational field, and daily beauty work, we analyze data from a survey called 'Everyday life and physical appearance'. The survey was fielded by the Unit of Economic Sociology at the University of Turku, Finland, in spring 2016 as a part of a project called 'Finland as an appearance society'. To our knowledge, this is the first population-level survey to inquire into everyday appearance-related practices, inequalities, and norms. Four thousand Finnish-speaking Finns were randomly sampled from the Finnish Population Database and sent a postal survey, which included a personalized link for online response. A total of 280 respondents filled in the online survey, and 1320 responded by mail.

Six respondents could not be reached; hence, the final sample totaled 3994. Of these, 1600 responded, which yielded a $40 \%$ response rate. Such a response rate is in line with recent trends in population-level survey research (Koivula et al. 2016) and may be considered sufficient. As is typical for survey research, older women are somewhat overrepresented in our data, while younger men are underrepresented (Sarpila et al. 2016). To correct for these biases, we employ weights throughout the analyses to make the data correspond to the gender and age distribution of the Finnish population, aged 15 to 74.

\section{Variables}

The dependent variables in our analyses measure subjective experiences of appearancerelated sanctions in two important stages of working life: recruitment and advancement in terms of wages. Conceptually, our dependent variables measure whether individuals have experienced their aesthetic capital and labor (or the lack thereof) has been sanctioned in working life. As the survey was focused on the topic of physical appearance, respondents had already been prompted to think about their appearance-related consumption, practices, attitudes and experiences before responding to the items that comprise our dependent variables. On the same page of the survey, a preceding survey item specified respondents should consider their appearance as a whole, taking into account facial traits, body size and shape as well as style (clothing, hair, and grooming).

The survey items we analyze were a part of a wider survey battery, where respondents were asked about their experiences of appearance-related sanctions in different areas of life. Respondents were asked: 'When you look back at your life, have you experienced your physical appearance has had an effect on the following?'. We analyze the items 'getting a job' as well as 'getting a higher salary'. The response options included 'has had a positive effect' and 'has had a negative effect'. Respondents were instructed to leave the boxes empty if they had not experienced appearance having an effect, but could tick both boxes if they had experienced appearance having both a positive and a negative effect. It is clear that an individual can during their life experience both appearance-related perks and penalties in the labor market, particularly because appearance-related norms are field-specific (cf. Bourdieu 1984; Green 2014). Hence, our dependent variables 'Employment' and 'Salary' both have four categories, which 
we coded as 1 = positive effect, 2 = negative effect, 3 = both a positive and a negative effect, and $4=$ no effect. We interpret our dependent variables as reported subjective experiences of appearance-related beauty perks and penalties i.e. appearance-based sanctions. While experiences of appearance-related sanctions do not necessarily implicate employers' unequal treatment on the basis of looks (i.e., employer lookism), they are a likely proxy (Berry 2008). Further, we interpret negative and positive sanctions as sides of the same coin (cf. Pajunen et al. 2019): a perk for one employee is likely to be a penalty for another.

Our independent variables are gender, field of work, and time spent in front of the mirror. Gender was measured so that respondents only had two options, 'male' and 'female'. ${ }^{2}$ The field of work was originally inquired as an open response item, where respondents were asked to write down their most recent profession. The open responses were then ISCO-08-coded at the specificity of four digits, and thereafter categorized on the basis of Daniel Oesch's social class schema (Oesch 2020). Oesch's occupational class schema takes into account service sector growth, welfare state expansion, and rising female participation in working life. Beyond hierarchical divisions, it also addresses horizontal cleavages by emphasizing differences in work logic and marketable skills. The schema distinguishes jobs with an interpersonal work logic (i.e., face-to-face encounters and attending to others' demands) from jobs with a technical or organizational work logic. Jobs that follow an interpersonal work logic and require expertise and communicative skills are classed as sociocultural (semi-)professionals, while those that require social skills but do not require high levels of education are classed as service jobs. The category of service jobs comprises skilled (e.g., hairdressers, travel guides, child care workers) and routine service (e.g., waiters and bar tenders, security guards). It excludes e.g. secretaries and mail sorting clerks, whose work follows a more organizational work logic. (Oesch 2006.) The occupations included in Oesch's category of service workers are listed in Appendix 1.

In our analyses, Oesch's categories 15 (skilled service) and 16 (routine service) are coded as $1=$ service sector, while other fields of work are coded as $0=$ other sectors. While this dichotomization is drastic, the categorical nature of our dependent variables along with their uneven distribution makes it necessary-especially when combined with our relatively small data. All respondents who wrote down their most recent profession were included in our analyses, regardless of current employment status. This means that our sample includes responses from, for example, students, unemployed individuals, and retirees. As our dependent variables measure appearance-related working-life sanctions across the lifespan, including working life experiences of people who are currently outside labor markets poses no problem per se, yet it ought to be taken into account.

Our third independent variable, namely time in front of the mirror, was measured by asking survey respondents to evaluate the number of minutes they spend in front of the mirror on a normal day, including morning and evening rituals. We interpret this variable as a proxy for daily appearance-related labor. We argue that this measure captures the most routinized aspect of everyday aesthetic labor. Time in front of the mirror, as part of our everyday morning and evening routines, is likely to be quite stable (despite some fluctuation according to phase of life) (Kukkonen 2019). These repeating routines give people a sense of control and are an integral part of daily lives. Morning and evening routines ease the shift between home and work, and private and public (see Ehn \& Löfgren 2009; McCabe et al. 2017). Because of its routinised nature, we argue that 
time in front of the mirror is something that survey respondents can grasp, and which can be measured with a single question. It is worth noting, however, that appearancerelated labor extends beyond time spent in front of the mirror: for example, people spend time on what Van den Berg and Vonk term 'dress work', that is, on calibrating outfits and looks for work (2019). Further, our measure of routine aesthetic labor does not capture the more 'athletic' aspects of aesthetic labor market demands (cf. Huzell \& Larson 2001). In addition, the measure is not completely gender neutral. Although it arguably includes such gender-neutral routines such as brushing one's hair and teeth and washing one's face, it includes traditionally gendered routines as well, for example putting on make-up for women and moustache/beard shaving for men. Moreover, our measurement is a proxy, which probably suffers from social desirability bias: people do not wish to consider themselves vain (Kukkonen 2019).

As control variables we include age (18-74), area of living ('urban' vs. 'rural'), as well as education ('primary', 'secondary', and 'bachelor's or higher'). We do not control for income for two reasons. First, income is likely to be a consequence of our dependent variables: getting a job and getting a higher salary. Second, our survey data on income is incomplete and appears unreliable. ${ }^{3}$

\section{Methods}

The first part of our analyses is descriptive, and we look at simple cross-tabulations and conditional means. In the second, explanatory part of our analyses, we employ multinomial regression, which is an extension of logistic regression. While logistic regression is suitable for the analysis of dichotomous variables, multinomial regression is suitable in situations where the dependent variable has several unordered categories. The multinomial logit model basically fits separate binary logits for each pair of unordered outcome categories (Long \& Freese 2014). Multinomial logistic regression yields results similar to ordinary logistic regression, namely as odds ratios (OR). Our full models presented as odds ratios for all variables can be found in Appendices 1 and 2. In order to facilitate interpretation, the results section presents results from these models as average marginal effects (AME) only for the independent variables.

\section{Descriptive results}

We commence our descriptive analysis by cross-tabulating experiences of appearancerelated sanctions concerning employment and salary with gender. As Figure 1 shows, $41 \%$ of women and $39 \%$ of men have experienced physical appearance as having an effect on getting a job. While the majority of these experiences are positive, a total $8 \%$ of both men and women have experienced negative effects at some stage. What is noteworthy is how evenly these experiences are distributed among men and women. Indeed, experiences of physical appearance having an effect on getting a job do not appear more common among women than among men in Finland.

Experiences of getting a greater salary are rarer, and here we also find a gender difference. While $18 \%$ of women have experienced appearances as having an effect on securing a higher salary, such experiences are reported by $26 \%$ of men. Strikingly, 
Figure I Experiences of appearance-related sanctions in working life by gender.

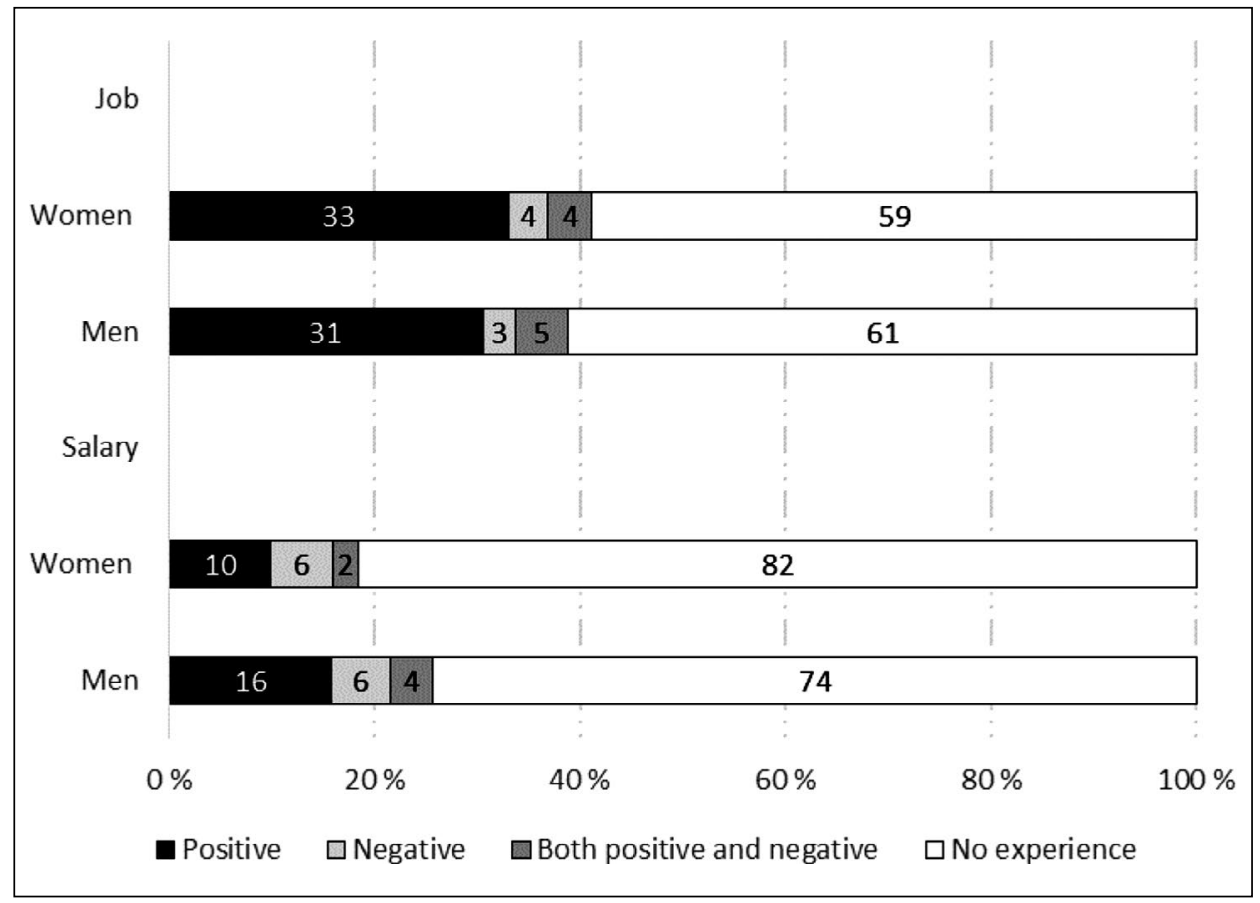

this difference is particularly due to men having significantly more positive experiences of physical appearance having an effect in gaining a higher salary than women $(16 \%$ versus $10 \%$ ).

Next, we cross-tabulate the experiences of appearance-related sanctions concerning employment and salary with the field of work. Figure $2 \mathrm{a}$ illustrates the experiences of appearance having had an effect on getting a job by the field of work. Comparing first the 'total' rows of results for men and women combined, we notice very little (one percentage point at largest) difference between experiences of people who work in the services and those who work in other industries. However, when we consider differences between men and women working in the service industries, women report more experiences of appearance having an effect on getting a job than men $(48 \%$ have some type of experience, compared to $34 \%$ of men). We find no remarkable gender differences among those working outside of service employment.

In Figure $2 \mathrm{~b}$, we can see that in total, experiences of appearance having an effect on getting a higher salary are somewhat as common among those working service jobs ( $24 \%$ have some kind of experience) as among those working other types of jobs $(22 \%$ have some kind of experience). What appears striking is the share of negative experiences among women working in the services $(11 \%)$, which is more than double, compared to that of women working in other jobs or men working in the services (both $4 \%$ ). It is noteworthy that the group with most experiences of appearance having an effect on 
Figure 2a Experiences of appearance having had an effect on getting a job by field of work and by gender.

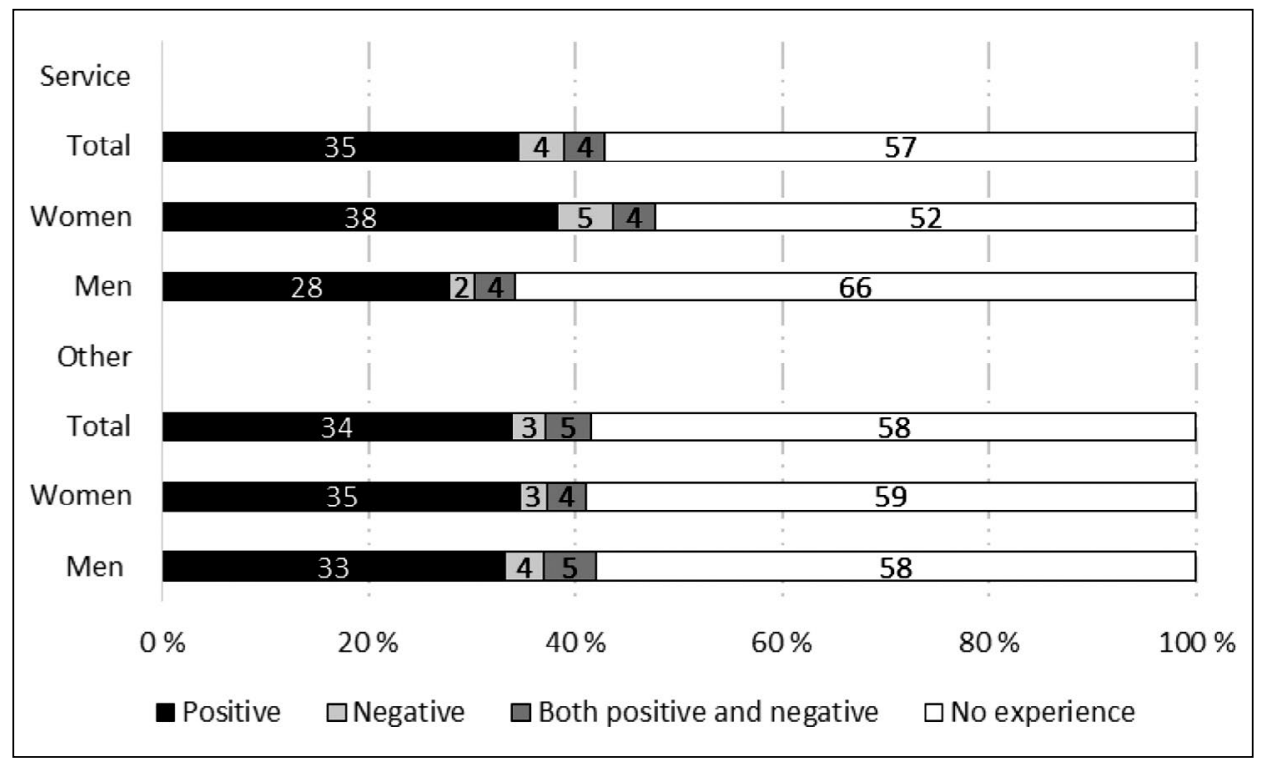

Figure 2b Experiences of appearance having had an effect on getting a higher salary by field of work and by gender.

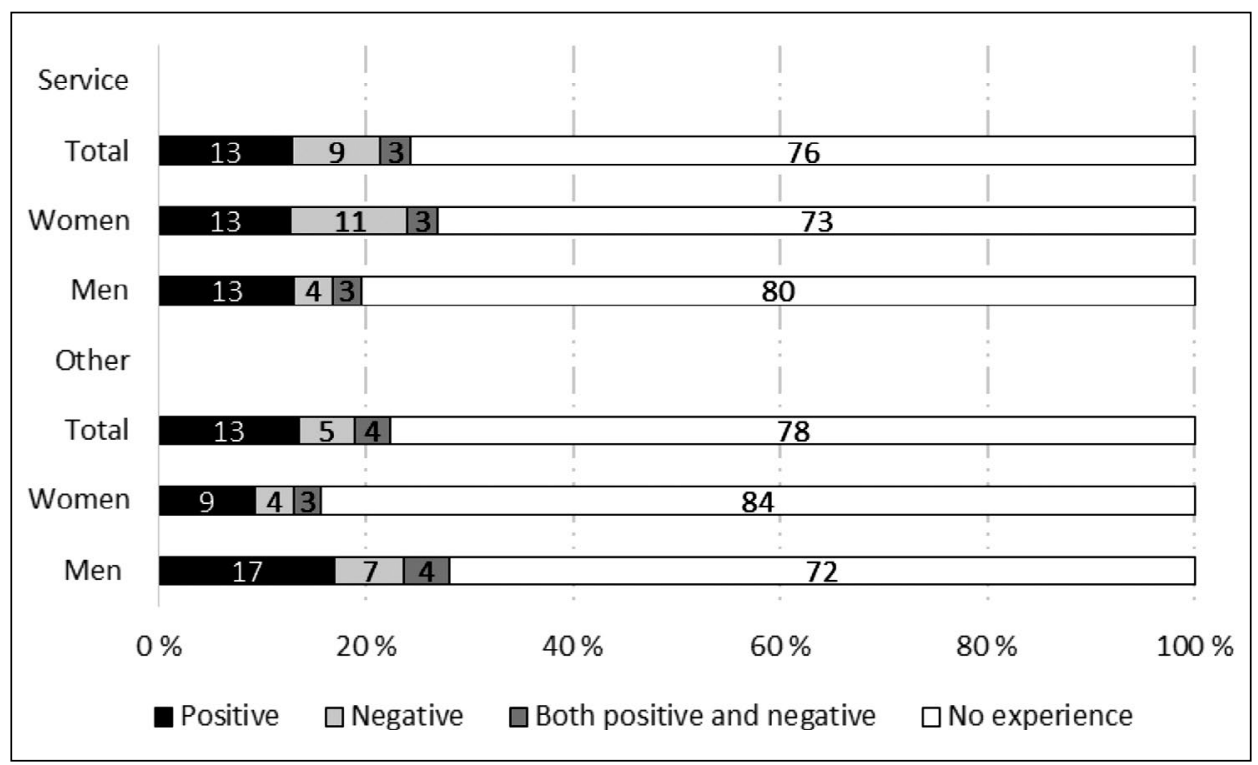


getting a higher salary is men working outside the service industries, and in particular their large share of experienced positive effects (17\%).

Finally, in order to descriptively explore our third research question, we examine the conditional means of daily appearance-related labor by our two dependent variables. Figure 3 a shows how many minutes a woman or man-who has a particular experience (or no experience) of appearance having an effect on getting a job-spends in front of the mirror on an average day. We can see women, on average, spend a significant amount of time in front of the mirror on a normal day, whereas men spend substantially less. Women who have experienced both positive and negative effects spend on average the most time in front of the mirror (28 minutes). Women who have experienced negative effects spend the least time in front of the mirror: twenty minutes on average. As for men, the variation in time spent in front of the mirror is small.

Figure $3 \mathrm{~b}$ shows how many minutes a woman or man-who has a particular experience (or no experience) of appearance having an effect on getting a higher salaryspends in front of the mirror on average. The distributions are remarkably similar across men with different experiences: all groups spend 7 minutes in front of the mirror on average. So are they for women: 23 minutes for all groups except for those who have experienced both negative and positive effects, who on average spend slightly less, 20 minutes, in front of the mirror on an average day.

Our descriptive analysis appears to suggest that time spent on grooming is not straightforwardly connected to experiences of appearance having an effect on the labor market. Next, we turn to the results from our explanatory analysis, which allow controlling for certain crucial issues-including age.

Figure 3a Conditional means of daily time spent in front of the mirror (min) by gender and experiences of appearance having had an effect on getting a job.

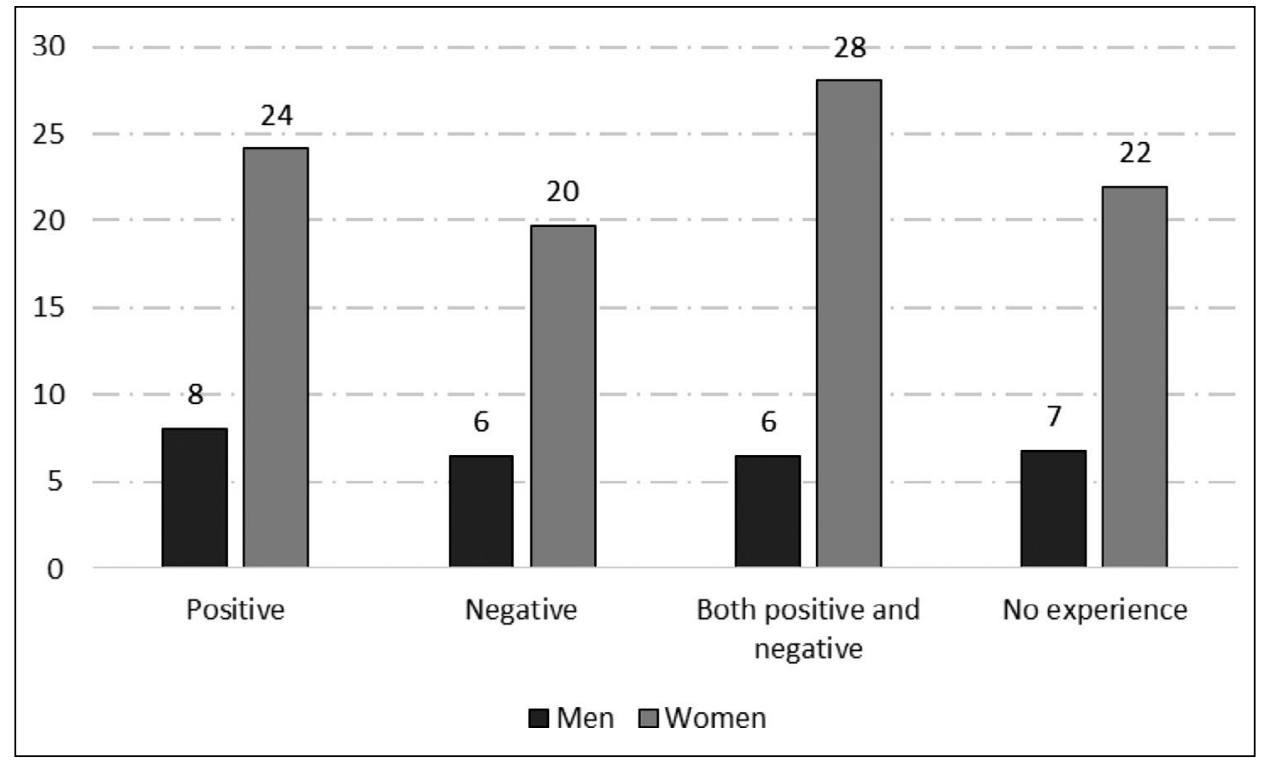


Figure 3b Conditional means of daily time spent in front of the mirror (min) by gender and experiences of appearance having had an effect on getting higher salary.

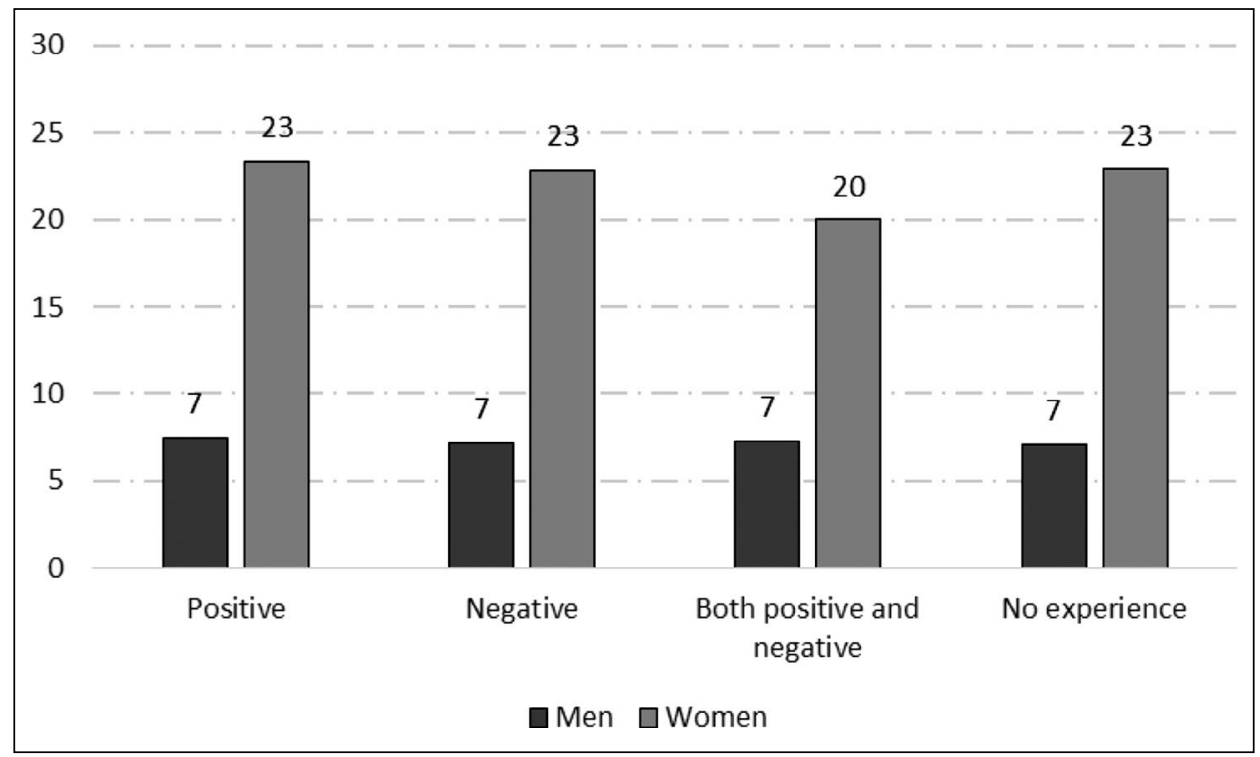

\section{Explanatory results}

In our first set of models, the dependent variables are regressed against all of our independent variables: gender, field of work, and daily time in front of the mirror, while controlling for education, area of living, and age. Table 1 presents the results from these regressions as predicted probabilities (OR results are presented in Appendix 2).

Pertaining to gender, these results confirm what our descriptive results suggested: there are no gender differences in experiences of appearance having an effect on getting

Table I Predicted probabilities for experiencing appearance having an effect on labor markets

\begin{tabular}{lcccccccc}
\hline & & \multicolumn{3}{c}{ Getting a job } & \multicolumn{4}{c}{ Getting a higher salary } \\
& Positive & Negative & Both & None & Positive & Negative & Both & None \\
\hline Female (ref. male) & -0.023 & 0.019 & -0.006 & 0.011 & $-0.063^{* *}$ & 0.004 & -0.011 & $0.069^{*}$ \\
& $(0.032)$ & $(0.015)$ & $(0.013)$ & $(0.034)$ & $(0.023)$ & $(0.015)$ & $(0.013)$ & $(0.028)$ \\
\hline Service sector & 0.011 & -0.002 & -0.016 & 0.007 & -0.005 & 0.015 & -0.009 & -0.001 \\
(ref. Other) & $(0.035)$ & $(0.012)$ & $(0.012)$ & $(0.037)$ & $(0.025)$ & $(0.017)$ & $(0.011)$ & $(0.030)$ \\
\hline Mirror time (min) & $0.004^{* * *}$ & -0.001 & 0.000 & $-0.003^{* *}$ & 0.001 & 0.000 & 0.000 & -0.001 \\
& $(0.001)$ & $(0.001)$ & $(0.000)$ & $(0.001)$ & $(0.001)$ & $(0.000)$ & $(0.001)$ & $(0.001)$ \\
\hline $\mathrm{N}$ & 1356 & 1356 & $\mid 356$ & 1356 & 1356 & 1356 & $\mid 356$ & 1356 \\
\hline
\end{tabular}

${ }^{+} \mathrm{p}<0.1,{ }^{*} \mathrm{p}<0.05,{ }^{* *} \mathrm{p}<0.01,{ }^{* * *} \mathrm{p}<0.001$ 
a job. On the other hand, the gender difference in experiences of appearance-related effects on getting a higher salary is significant even after controlling for other factors. Men are 6.3 percentage points more likely to experience appearance having a positive effect on having a higher salary $(\mathrm{p}=0.005)$. In contrast, women were 6.9 percentage points more likely $(\mathrm{p}=0.012)$ to not have experienced appearance-related perks or penalties in gaining more salary. It would thus appear that if appearances are a gendered asset in working life, then in Finland they are more of a male asset.

We find no statistically significant results for the field of work: overall, Finns working in the services appear to be no more prone to experiences of appearance-related working-life perks and penalties than Finns working in other sectors of working life. As for mirror time, Table 1 suggests that one extra daily minute spent in front of the mirror increases the probability of having positive experiences of appearance-related effects in getting a job by 0.4 percentage points $(\mathrm{p}=0.000)$, and decreases the probability of not experiencing any appearance-related perks or penalties by 0.3 percentage points $(\mathrm{p}=0.007)$. However, additional minutes spent daily grooming do not appear to have a significant connection to the 'negative' or 'both positive and negative' outcomes. Further, we find that mirror time does not appear to be connected to experiences of appearance having an effect on getting a higher salary.

Considering the gender differences in our descriptive results pertaining to the field of work and mirror time, it makes sense to elaborate the analysis conducting separate regressions for men and women. Table 2 a shows predicted probabilities for experiencing appearance having an effect on getting a job separately for women and for men (full results are included in Appendix 3a).

Table $2 \mathrm{a}$ shows, first of all, that experiences of appearance having an effect on getting a job are similar for those working in service industries and those working in other fields, for women as well as for men. Second, we see that the effect of mirror time applies to women only. For women, one extra daily minute spent in front of the mirror increases the probability of having positive experiences of appearance-related effects in getting a job by 0.4 percentage points $(\mathrm{p}=0.001)$, and decreases the probability of not experiencing any appearance-related perks or penalties by 0.3 percentage points $(\mathrm{p}=0.023)$. For men, the additional time spent in front of the mirror does not contribute to the probability of experiencing appearance-related perks and penalties.

Table 2a Predicted probabilities for experiencing appearance having an effect on getting a job. Separate models for men and women

\begin{tabular}{lccccccccc}
\hline & \multicolumn{4}{c}{ Men } & \multicolumn{5}{c}{ Women } \\
& Positive & Negative & Both & None & Positive & Negative & Both & None \\
\hline $\begin{array}{l}\text { Service sector } \\
\text { (ref. Other) }\end{array}$ & -0.047 & -0.015 & -0.016 & 0.077 & 0.062 & 0.009 & -0.007 & -0.063 \\
& $(0.058)$ & $(0.018)$ & $(0.021)$ & $(0.061)$ & $(0.043)$ & $(0.017)$ & $(0.014)$ & $(0.045)$ \\
\hline Mirror time (min) & 0.004 & -0.000 & -0.001 & -0.004 & $0.004^{* *}$ & -0.001 & 0.000 & $-0.003^{*}$ \\
& $(0.003)$ & $(0.00 \mathrm{I})$ & $(0.002)$ & $(0.003)$ & $(0.001)$ & $(0.001)$ & $(0.000)$ & $(0.00 \mathrm{I})$ \\
\hline $\mathrm{N}$ & 576 & 576 & 576 & 576 & 780 & 780 & 780 & 780 \\
\hline
\end{tabular}

${ }^{+} \mathrm{p}<0.1,{ }^{*} \mathrm{p}<0.05,{ }^{* *} \mathrm{p}<0.01,{ }^{* * *} \mathrm{p}<0.001$

Age, education, and area of living are controlled for. For full results (OR), see Appendix 3a. 
Table 2b Predicted probabilities for experiencing appearance having an effect on getting a higher salary

\begin{tabular}{lccccccccc}
\hline & \multicolumn{4}{c}{ Men } & \multicolumn{5}{c}{ Women } \\
& Positive & Negative & Both & None & Positive & Negative & Both & None \\
\hline Service sector & -0.036 & $-0.037^{+}$ & -0.016 & $0.089^{+}$ & 0.023 & $0.046^{+}$ & -0.003 & $-0.066^{+}$ \\
(ref. Other) & $(0.044)$ & $(0.022)$ & $(0.020)$ & $(0.050)$ & $(0.028)$ & $(0.026)$ & $(0.012)$ & $(0.038)$ \\
\hline Mirror time (min) & 0.000 & 0.000 & 0.000 & -0.001 & 0.001 & 0.000 & 0.000 & -0.001 \\
& $(0.003)$ & $(0.001)$ & $(0.001)$ & $(0.003)$ & $(0.001)$ & $(0.000)$ & $(0.001)$ & $(0.001)$ \\
\hline$N$ & 576 & 576 & 576 & 576 & 780 & 780 & 780 & 780 \\
\hline
\end{tabular}

${ }^{+} p<0.1,{ }^{*} p<0.05,{ }^{* *} p<0.01,{ }^{* * *} p<0.001$

Age, education, and area of living are controlled for. For full results (OR), see Appendix 3b.

Table $2 \mathrm{~b}$ shows predicted probabilities for experiencing appearance having an effect on getting a higher salary for women and men (full results are available in Appendix 3b). In contrast to Table 1, which shows results for women and men combined and where we see no difference in experiences between those working in the service sector and those working in other sectors, the elaboration conducted in Model $2 \mathrm{~b}$ shows that there are likely differences between sectors. It is just that they are quite the opposite for women as they are for men. Men working in the service sector appear somewhat less likely (3.7 percentage points, $\mathrm{p}=0.088$ ) to have negative experiences of appearance playing a role in getting greater salary than men working in other sectors. Moreover, they seem more likely ( 8.9 percentage points, $\mathrm{p}=0.075)$ to not have experienced any type of appearance-related working-life sanctions than men working in other fields. Women working in the service sector, in contrast, appear more likely (4.6 percentage points, $\mathrm{p}=0.081)$ to have negative experiences of appearance playing an effect in getting a higher salary than women working in other sectors. Further, compared to women working in other fields, they seem less likely $(6.6$ percentage points, $\mathrm{p}=0.080)$ to never have experienced any type of appearance-related sanctions. Hence, it appears that the service sector is a field of increased appearance-related vulnerability for women, while men seem more vulnerable to appearance-related sanctions if they work other types of jobs.

\section{Discussion}

In this study, we explored experiences of appearance-related sanctions, that is perks and penalties, in the Finnish labor market. By employing unique national-level survey data, we examined whether men and women equally experience appearance-related sanctions in working life, and if so, whether such gendered experiences were equally common in service industries, compared with other fields of work. Further, we investigated whether the potentially gendered experiences of such sanctions were dependent on daily beauty work. Our first finding is that these sanctions are not just experienced by women, but also concern men. In fact, men are more likely to have experienced their salary negotiations being influenced by appearance, and in particular, appear more likely to have experienced their appearances financially rewarded in terms of higher salary. Secondly, we 
found that compared to other sectors, women are more likely to experience appearancerelated sanctions in the service sector, whereas the case may be opposite for men. Third, while daily work on one's appearance has a positive association with women's experiences of appearance-related perks in terms of getting a job-it far from always 'pays off'.

Our first and main finding, that it is not women but rather men who experience more appearance-related perks may appear surprising in light of lay understandings. However, this is in line with previous research on the (socio)economic consequences of physical appearance, where the empirical debate on whether appearances matter more for men or women, remains unsolved (cf. Hosoda et al. 2003; Maestripieri et al. 2017). This finding is also in line with recent research, which suggests that while women are expected to work and consume on their appearances, their possibilities for gaining benefit from their appearances in working life are restricted (Sarpila et al. 2020, see also Mears 2015a, 2015b). Further, it is clear that on gender-segregated labor markets, such as the Finnish one, men are more often in a position to affect e.g. their salaries in the first place.

Second, we find that experiences of appearance-related sanctions in recruitment are alike for Finnish men and women in the service sector, as well as beyond. However, at the point of salary negotiations, we find slight support for field-specific variation in gendered experiences of appearance-related sanctions. Our results hint that women in the service sector may be more vulnerable to experiences of appearance-related discrimination than women in other industries. In contrast, men in the services appear less vulnerable to such experiences than men working in other industries. This finding could be due to women and men working in different parts of the service sector. Nevertheless, these exploratory and tentative findings suggest that appearance may be of different importance for men and women in different sectors of working life. Further, while expectations for aesthetic labor may well be particularly blatant in the interactive service sector, our results would suggest that appearance-related sanctions are equally prevalent in industries outside the services, and indeed the largest prevalence is found for men working outside the service industries. This suggests that sanctioning not only happens in feminine interactive service industries and in relations between customers, servers, and service employers.

Third, we find that beauty work is connected to women's experiences of appearance-related perks in terms of getting a job. We also find that women who spend more time in front of the mirror are less likely to have foregone appearance-related sanctions in recruitment. Beauty work does not appear to shield women from the negative sides of appearance-related discrimination. Speaking in economists' terms, 'investment' in appearance-related capital does not always appear to be a very profitable investment (Das \& De Loach 2011; Hamermesh et al. 2002). Even though such capital is increasingly valued in working life and women seemingly 'invest' in such capital, it does not automatically mean that women experience profits from it (cf. Mears 2015a, 2015b; Wolf 2002). Wolf's analysis suggests that appearance-related norms for women intensify whenever women gain more power. As women are reduced to their looks and busy working on their bodies, working life can more easily remain patriarchal (2002). Our data show that Finnish women spend significantly more time in front of the mirror than men do, partly because women are expected to be 'made-up' (Kukkonen 2019). Hence, many women are already doing their best to engage in 'aesthetic labor'. Men do not work much on their looks but experience rewards for their looks equally if not more.

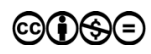


While for some women, beauty work may be of use in entering the labor market, it is also worth stressing that Finland has a very gender-segregated labor market (Grönlund et al. 2017). One female employee's appearance-related perk is thus often a penalty for another female employee-the same goes for men.

Our study, of course, has several important limitations worth highlighting, besides those already discussed in the data and methods section. First, our results have little explanatory power, which suggests experiences of appearance-related working-life perks and penalties certainly ought not to be reduced to gender, dichotomized field of work, or beauty work. Importantly, the present data did not allow us to examine the occupational field-specificity of appearance-related sanctions with any precision or detail. Second, our dependent variables, which measure experiences of physical appearance having an effect on working life, leave much up for interpretation. We do not know what these subjective experiences were like and whether they were perceived as discriminatory.

Our results must be situated in the context of a Nordic 'women-friendly' welfare state. The Nordic countries, however, are not monoliths and differ in their policies and institutionalization of gender equality (Borchorst \& Siim 2002; Grönlund et al. 2017) as well as their anti-discrimination legalization. Furthermore, countries have their own national fashion systems (Crane \& Bovone 2006) and gendered physical appearancerelated taste repertoires (Kuipers 2015), which are not prescribed by their institutions and policies alone. Future studies could look at how and why the prevalence and acceptance of physical appearance-related inequalities in working life are gendered in different countries and in time. Nordic comparisons would be timely, as would public discussions on the legal state of appearance-based discrimination in Nordic countries. More generally, future research on appearance-related inequalities in working life could focus on how aesthetic labor and appearance-related sanctioning takes place between various actors (including colleagues; cf. Van den Berg \& Vonk 2020) and in industries outside the usual suspects of the feminine, interactive services. Future studies could also further investigate how appearance-related sanctioning or lookism is intermeshed with other forms of working-life sanctions or discrimination, including agism, ableism, racism and sexism.

While much attention has been paid to gender segregation in Nordic labor markets, the role played by physical appearance in gender equality has often been neglected. As work on gender equality proceeds in the Nordic countries, it would be crucial to take a serious look at the appearance-related labor women engage in. If the role of appearances in post-fordist economies goes without notice, appearance-related inequalities may accumulate to the point of challenging the 'gender equal' premises set up by the Nordic welfare states. The Nordic countries have been among the most successful in working to alleviate the feminine burden of the second shift. Should decreasing the burden of the so-called third shift of beauty work also be on the agenda?

Our study showed that experiences of appearance-related sanctions in working life are common even in Nordic countries such as Finland. This indicates that appearancerelated inequalities are embedded in the structures of welfare states. For example, it is possible that women are so used to being evaluated on the basis of their looks that they do not even pay much notice to appearance-related sanctions. Furthermore, it is probable that appearance-related discrimination is more common than what people report, since employees are typically not made aware of looks-based penalties (cf. Berry 2008). As we measured subjective experiences of sanctions, our results may just hint at the tip of an iceberg of gendered appearance-based labor market discrimination in the Nordic countries. 


\section{References}

Adamson, M., \& Salmenniemi, S. (2017). 'The bottom line is that the problem is you': aesthetic labour, postfeminism and subjectivity in Russian self-help literature. In: Elias, A. S., Gill, R. \& Scharff, C. (eds.) Aesthetic Labour, 301-316. London: Palgrave Macmillan.

Anderson, T. L., Grunert, C., Katz, A. \& Lovascio, S. (2010). Aesthetic capital: A research review on beauty perks and penalties, Sociology Compass 4(8): 564-575. doi: https://doi. org/10.1111/j.1751-9020.2010.00312.x.

Berggren, N., Jordahl, H. \& Poutvaara, P. (2017). The right look: Conservative politicians look better and voters reward it, Journal of Public Economics 146: 79-86. doi: https:// doi.org/10.1016/j.jpubeco.2016.12.008.

Berry, B. (2008). The Power of Looks: Social Stratification of Physical Appearance, Routledge.

Bolsø, A. \& Mühleisen, W. (2017). Representations of women dressed for power. In: Bolsø, A., Svendsen, S. \& Sørensen, S. (eds.) Bodies, Symbols and Organizational Practice, 12-33. Abigdon: Routledge.

Borchorst, A. \& Siim, B. (2002). The women-friendly welfare states revisited, NORA: Nordic Journal of Women's Studies 10(2): 90-98. doi: https://doi.org/10.1080/08038 7402760262186.

Bourdieu, P. (1984). Distinction: A Social Critique of the Judgement of Taste, Harvard University Press.

Bourdieu, P. (1986). The forms of capital. In: Richardson, J. (ed.) Handbook of Theory and Research for the Sociology of Education, 241-258, Greenwood.

Boyle, B. \& De Keere, K. (2019). Aesthetic labour, class and taste: Mobility aspirations of middle-class women working in luxury-retail, The Sociological Review 67(3): 706-722. doi: https://doi.org/10.1177/0038026119827753.

Dahl, D. B. (2013). Looking neat on the street. Aesthetic labor in public parking patrol, Nordic Journal of Working Life Studies 3(2): 59-78.

Crane, D. \& Bovone, L. (2006). Approaches to material culture: The sociology of fashion and clothing, Poetics 34(6): 319-333. doi: https://doi.org/10.1016/j.poetic.2006.10.002.

Das, J. \& De Loach, S. B. (2011). Mirror, mirror on the wall: The effect of time spent grooming on earnings, The Journal of Socio-Economics 40(1): 26-34. doi: https://doi. org/10.1016/j.socec.2010.06.005.

Edmonds, A. \& Mears, A. (2017). Managing body capital in fields of labor, sex, and health. In: Anderson-Fye, E., Brewis Slade (eds.) Fat Planet. Santa Fe: SAR Press.

Ehn, B. \& Löfgren, O. (2009). Routines-made and unmade. In: Shove, E., Trentmann, F \& Wilk, R. (eds.) Time, Consumption and Everyday Life. Practice, Materiality and Culture, 99-112. Oxford: Berg.

Elias, A., Gill, R. \& Scharff, C. (2017). Aesthetic labour: Beauty politics in neoliberalism. In: Elias, A. S., Gill, R. \& Scharff, C. (eds.) Aesthetic Labour, 3-49. London: Palgrave Macmillan.

Entwistle, J. \& Wissinger, E. (2006). Keeping up appearances: aesthetic labour in the fashion modelling industries of London and New York, The Sociological Review 54(4): 774-794. doi: https://doi.org/10.1111/j.1467-954X.2006.00671.x.

Eurobarometer (2019). Discrimination in the European Union 2019, Special Eurobarometer 493, European Commission.

Gill, R. (2017). The affective, cultural and psychic life of postfeminism: A postfeminist sensibility 10 years on, European Journal of Cultural Studies 20(6): 606-626. doi: https://doi. org/10.1177/1367549417733003.

Green, A. I. (2014). The sexual fields framework. In: Green, A. I. (ed.) Sexual fields: Toward a sociology of collective sexual life, 25-56. University of Chicago Press. 
Grönlund, A., Halldén, K. \& Magnusson, C. (2017). A Scandinavian success story? Women’s labour market outcomes in Denmark, Finland, Norway and Sweden, Acta Sociologica 60(2): 97-119. doi: https://doi.org/10.1177/0001699316660595.

Hamermesh, D. S., Meng, X. \& Zhang, J. (2002). Dress for success-does primping pay?, Labour Economics 9(3): 361-373. doi: https://doi.org/10.1016/S0927-5371(02)00014-3.

Hamermesh, D. S. (2011). Beauty Pays. Why Attractive People are more Successful, Princeton University Press.

Hernes, H. M. (1987). Welfare State and Woman Power: Essays in State Feminism, A Scandinavian University Press Publication.

Hochschild, A. R. \& Machung, A. (2012). The Second Shift: Working Families and the Revolution at Home, Penguin.

Holla, S. \& Kuipers, G. (2015). Aesthetic capital. In: Hanquinet, L. \& Savage, M. (eds) Routledge International Handbook of the Sociology of Art and Culture, 290-304, London: Routledge.

Hosoda, M., Stone-Romero, E. F. \& Coats, G. (2003). The effects of physical attractiveness on job-related outcomes: A meta-analysis of experimental studies, Personnel Psychology 56(2): 431-462. doi: https://doi.org/10.1111/j.1744-6570.2003.tb00157.x.

Hracs, B. J. \& Leslie, D. (2014). Aesthetic labour in creative industries: the case of independent musicians in Toronto, Canada, Area 46(1): 66-73.

Huzell, H. \& Larsson, P. (2012). Aesthetic and athletic employees: The negative outcome of employers assuming responsibility for sickness benefits, Economic and Industrial Democracy 33(1): 103-123. doi: https://doi.org/10.1177/0143831X11427590.

Härkönen, J., Räsänen, P. \& Näsi, M. (2011). Obesity, unemployment, and earnings, Nordic Journal of Working Life Studies 1(2): 23-38. doi: https://doi.org/10.19154/njwls.v1i2.2343.

Kinnunen, T. \& Parviainen, J. (2016). Rekrytointikonsulttien tuntuma "hyvästä tyypistä" [Recruitment consultants' feel of a "good fellow"]. In: Parviainen, J., Kinnunen, T. \& Kortelainen, I. (eds.) Ruumiillisuus ja työelämä: Työruumis jälkiteollisessa taloudessa [Embodiment and working life: The working body in the postindustrial economy], 59-75, Tampere: Vastapaino.

Koivula, A., Räsänen, P., \& Sarpila, O. (2016). Internet- ja paperilomakkeiden täyttäjät: vastaustavan muutoksen ja merkityksen arviointia hyvinvointitutkimuksessa [Web and survey respondents: response mode effects in wellbeing research]. Yhteiskuntapolitiikka [Public policy] 81(2), 54-65.

Kuipers, G. (2015). Beauty and distinction? The evaluation of appearance and cultural capital in five European countries, Poetics 53: 38-51. doi: https://doi.org/10.1016/j.poetic. 2015.10.001.

Kukkonen, I., Åberg, E., Sarpila, O. \& Pajunen, T. (2018). Exploitation of aesthetic capitaldisapproved by whom? International Journal of Sociology and Social Policy 38(3/4), $312-328$.

Kukkonen, I. (2019) Aikaa, jonka voisi käyttää myös paremmin? Feministisiä näkökulmia kauneuskäytänteisiin. [Time that might also have better use? Feminist approaches to beauty practices.] In: Kukkonen, I., Pajunen, T., Sarpila, O. \& Åberg, E. (eds.) Ulkonäköyhteiskunta: Ulkoinen olemus pääomana 2000-luvun Suomessa [Appearance society: Physical appearance as a form of capital in 21st century Finland], 123-136, Helsinki: Into Kustannus Oy.

Laustsen, L. (2014). Decomposing the relationship between candidates' facial appearance and electoral success, Political Behavior 36(4): 777-791. doi: https://doi.org/10.1007/ s11109-013-9253-1.

Lister, R. (2009). A Nordic nirvana? Gender, citizenship, and social justice in the Nordic welfare states, Social Politics: International Studies in Gender, State \& Society 16(2): 242-278. doi: https://doi.org/10.1093/sp/jxp007. 
Long, J. S. \& Freese, J. (2014). Regression models for Categorical Variables using Stata ( $3^{\text {rd }}$ ed), Texas: Stata Press.

Luna, J. K. (2019). The ease of hard work: embodied neoliberalism among Rocky Mountain fun runners, Qualitative Sociology 42(2): 251-271. doi: https://doi.org/10.1007/s11133 019-9412-8.

Maestripieri, D., Henry, A. \& Nickels, N. (2017). Explaining financial and prosocial biases in favor of attractive people: Interdisciplinary perspectives from economics, social psychology, and evolutionary psychology, Behavioral and Brain Sciences 40. doi: https://doi. org/10.1017/S0140525X16000340.

Martin, J. L. \& George, M. (2006). Theories of sexual stratification: Toward an analytics of the sexual field and a theory of sexual capital, Sociological Theory 24(2): 107-132. doi: https://doi.org/10.1111/j.0735-2751.2006.00284.x.

McCabe, M., de Waal Malefyt, T. \& Fabri, A. (2017). Women, makeup, and authenticity: Negotiating embodiment and discourses of beauty, Journal of Consumer Culture. doi: https://doi.org/10.1177/1469540517736558.

McDowell, L. (2009). Working Bodies: Interactive Service Employment and Workplace Identities, John Wiley \& Sons.

McRobbie, A. (2009). The Aftermath of Feminism: Gender, Culture and Social Change, London: Sage.

Mears, A. (2014). Aesthetic labor for the sociologies of work, gender, and beauty, Sociology Compass 8(12): 1330-1343. doi: https://doi.org/10.1111/soc4.12211.

Mears, A. (2015a). Working for free in the VIP: Relational work and the production of consent, American Sociological Review 80(6): 1099-1122. doi: https://doi.org/10.1177/ $\underline{0003122415609730 .}$.

Mears, A. (2015b). Girls as elite distinction: The appropriation of bodily capital, Poetics 53: 22-37. doi: https://doi.org/10.1016/j.poetic.2015.08.004.

Meriläinen, S., Tienari, J. \& Valtonen, A. (2015). Headhunters and the 'ideal' executive body, Organization 22(1), 3-22. doi: https://doi.org/10.1177/1350508413496578.

Neumann, C. B. (2017). A dangerous subject: the fashion model and the beauty/narcissism double bind, Hypatia 32(2), 380-396. doi: https://doi.org/10.1111/hypa.12319.

Oesch, D. (2006). Coming to grips with a changing class structure: An analysis of employment stratification in Britain, Germany, Sweden and Switzerland, International Sociology 21(2): 263-288. doi: https://doi.org/10.1177/0268580906061379.

Oesch, D. (2020). Scripts for Social Class. Available at: https://people.unil.ch/danieloesch/ scripts/ [Accessed 14 January, 2020].

Pajunen, T., Kukkonen, I. \& Sarpila, O. (2019). Normit ihon alla: Kokemuksia ulkonäköpaineista [Norms beneath the skin: Experiences of appearance-related pressures]. In: Kukkonen, I., Pajunen, T., Sarpila, O. \& Åberg, E. (eds.) Ulkonäköyhteiskunta: Ulkoinen olemus pääomana 2000-luvun Suomessa [Appearance society: Physical appearance as a form of capital in 21st century Finland], 157-171, Helsinki: Into Kustannus Oy.

Pettinger, L. (2004). Brand culture and branded workers: Service work and aesthetic labour in fashion retail, Consumption Markets \& Culture 7(2): 165-184. doi: https://doi.org/ $10.1080 / 1025386042000246214$.

Pettinger, L. (2008). Developing aesthetic labour: The importance of consumption, International Journal of Work Organisation and Emotion 2(4): 327-343. doi: https://doi. org/10.1504/IJWOE.2008.022495.

Robins, P. K., Homer, J. F. \& French, M. T. (2011). Beauty and the labor market: Accounting for the additional effects of personality and grooming, Labour 25(2): 228-251. doi: https://doi.org/10.1111/j.1467-9914.2010.00511.x. 
Rooth, D. O. (2009). Obesity, attractiveness, and differential treatment in hiring a field experiment, Journal of Human Resources, 44(3): 710-735. doi: https://doi.org/10.3368/ jhr.44.3.710.

Sarpila, O. \& Åberg, E. (2019). Ulkonäkökulutuksella kohti parempaa minää ja elämää? [Towards a better me and a better life by means of appearance-related consumption?]. In: Kukkonen, I., Pajunen, T., Sarpila, O. \& Åberg, E. (eds.) Ulkonäköyhteiskunta: Ulkoinen olemus pääomana 2000-luvun Suomessa [Appearance society: Physical appearance as a form of capital in $21^{\text {st }}$ century Finland], 103-118, Helsinki: Into Kustannus Oy.

Sarpila, O., Sandell, R., Koivula, A. \& Kukkonen, I. (2016). Arkielämä ja ulkonäkö -kyselyn tutkimusseloste [Research report on the Physical appearance and everyday life -survey]. Working papers in Economic Sociology, University of Turku. Available online at: https:// www.utu.fi/sites/default/files/public \% 3A//media/file/Arkiel\%C3\%A4m\%C3\% $\overline{\mathrm{A} 4 \text { ja }}$ ulkon \% C3\% A4k\%C3\%B6 kyselyn tutkimusseloste.pdf [Accessed 12 October 2020].

Sarpila, O., Pajunen, T., Kekäläinen, S. \& Åberg, E. (2017). Onko ulkonäön arvostus nousussa Suomessa? [Is the valuation of physical appearance increasing in Finland?], Yhteiskuntapolitiikka [Public policy] 82(1): 86-93.

Sarpila, O., Koivula, A., Kukkonen, I., Åberg, E. \& Pajunen, T. (2020). Double standards in the accumulation and utilisation of 'aesthetic capital'. Poetics. doi: https://doi.org/10.1016/j. poetic. 2020.101447.

Siim, B. \& Skjeie, H. (2008). Tracks, intersections and dead ends: Multicultural challenges to state feminism in Denmark and Norway, Ethnicities 8(3): 322-344. doi: https://oi. org/10.1177/1468796808092446.

Skeggs, B. (2004). Class, Self, Culture, London: Routledge.

Swedberg, R. (2003). Principles of Economic Sociology, New Jersey: Princeton University Press.

van den Berg, M. \& Arts, J. (2019). The aesthetics of work-readiness: Aesthetic judgements and pedagogies for conditional welfare and post-Fordist labour markets, Work, Employment and Society 33(2): 298-313. doi: https://doi.org/10.1177/0950017018758196.

van den Berg, M. \& Vonk, L. (2019). The new discomforts of precarious workers: Wardrobe matter, insecurity and the temporality of calibration in dress work, The Sociological Review. doi: https://doi.org/10.1177/0038026119892402.

Villar, J. G. \& Quintana-Domeque, C. (2009). Income and body mass index in Europe, Economics \& Human Biology 7(1): 73-83. doi: https://doi.org/10.1016/j.ehb.2009.01.006.

Wacquant, L. J. (1995). Pugs at work: Bodily capital and bodily labour among professional boxers, Body \& society 1(1): 65-93.doi: https://doi.org/10.1177/1357034X95001001005.

Warde, A. (2005). Consumption and theories of practice, Journal of Consumer Culture 5(2): 131-153. doi: https://doi.org/10.1177/1469540505053090.

Warhurst, C. \& Nickson, D. (2001). Looking Good, Sounding Right. Style Counselling in the New Economy, London: The Industrial Society. doi: https://doi.org/10.1108/096045205 10585370.

Williams, C. L. \& Connell, C. (2010). “Looking good and sounding right”: Aesthetic labor and social inequality in the retail industry, Work and Occupations 37(3): 349-377. doi: https://doi.org/10.1177/0730888410373744.

Witz, A., Warhurst, C. \& Nickson, D. (2003). The labour of aesthetics and the aesthetics of organization, Organization 10(1): 33-54. doi: https://doi.org/10.1177/1350508403010001375.

Wong, J. S. \& Penner, A. M. (2016). Gender and the returns to attractiveness, Research in Social Stratification and Mobility, 44: 113-123. doi: https://doi.org/10.1016/j.rssm.2016.04.002.

Wolf, N. (2002). The Beauty Myth: How Images of Beauty are Used Against Women, Harper Collins.

World Economic Forum (2020). Global Gender Gap Report 2020. Available at: https:// www.weforum.org/reports/gender-gap-2020-report-100-years-pay-equality [Accessed 19 February 2020]. 


\section{Notes}

${ }^{1}$ Although Bourdieu does appear to suggest beauty can, in certain cases, shake up the class system generally based on cultural, economic, and social capital (Bourdieu 1984, 214).

${ }^{2}$ We acknowledge that measuring and treating gender as a binary is problematic and encourage all survey designs to take into account nonbinary people.

${ }^{3}$ We have many missing responses $(10 \%)$, the data does not in the least correspond to the income of the population, has multiple observations of 0 euros while in Finland social security secures everyone at least an income of a few hundred, includes further anomalies such as cases where it is clear annual income has been reported in lieu of monthly. 
Appendix I Categorization of service jobs according to Oesch (2020)

\begin{tabular}{|c|c|c|c|}
\hline ISCO-08 & \begin{tabular}{|l} 
Skilled service \\
(Oesch category 15)
\end{tabular} & ISCO-08 & \begin{tabular}{|l|} 
Low-skilled service \\
(Oesch category 16)
\end{tabular} \\
\hline 324 & Veterinary technicians and assistants & 513 & Waiters and bartenders \\
\hline 3240 & Veterinary technicians and assistants & 5131 & Waiters \\
\hline 3251 & Dental assistants and therapists & 5132 & Bartenders \\
\hline 3258 & Ambulance workers & 515 & Building and housekeeping supervisors \\
\hline 342 & Sports and fitness workers & 5151 & $\begin{array}{l}\text { Cleaning and housekeeping } \\
\text { supervisors in offices, hotels and other } \\
\text { establishments }\end{array}$ \\
\hline 3421 & Athletes and sports players & 5152 & Domestic housekeepers \\
\hline 3422 & $\begin{array}{l}\text { Sports coaches, instructors and } \\
\text { officials }\end{array}$ & 5153 & Building caretakers \\
\hline 3423 & $\begin{array}{l}\text { Fitness and recreation instructors } \\
\text { and program leaders }\end{array}$ & 516 & Other personal services workers \\
\hline 3434 & Chefs & 5161 & $\begin{array}{l}\text { Astrologers, fortune-tellers and related } \\
\text { workers }\end{array}$ \\
\hline 5 & Service and sales workers & 5162 & Companions and valets \\
\hline 51 & Personal service workers & 5164 & Pet groomers and animal care workers \\
\hline 511 & $\begin{array}{l}\text { Travel attendants, conductors and } \\
\text { guides }\end{array}$ & 5169 & $\begin{array}{l}\text { Personal services workers not } \\
\text { elsewhere classified }\end{array}$ \\
\hline 5111 & Travel attendants and travel stewards & 521 & Street and market salespersons \\
\hline 5112 & Transport conductors & 5211 & Stall and market salespersons \\
\hline 5113 & Travel guides & 5212 & Street food salespersons \\
\hline 512 & Cooks & 524 & Other sales workers \\
\hline 5120 & Cooks & 5243 & Door to door salespersons \\
\hline 514 & $\begin{array}{l}\text { Hairdressers, beauticians and related } \\
\text { workers }\end{array}$ & 5244 & Contact centre salespersons \\
\hline $5|4|$ & Hairdressers & 5245 & Service station attendants \\
\hline 5142 & Beauticians and related workers & 5246 & Food service counter attendants \\
\hline 5163 & Undertakers and embalmers & 5249 & Sales workers not elsewhere classified \\
\hline 5165 & Driving instructors & 5322 & Home-based personal care workers \\
\hline 52 & Sales workers & 5329 & $\begin{array}{l}\text { Personal care workers in health } \\
\text { services not elsewhere classified }\end{array}$ \\
\hline 522 & Shop salespersons & 5414 & Security guards \\
\hline 5222 & Shop supervisors & 8322 & Car, taxi and van drivers \\
\hline 5223 & Shop sales assistants & 91 & Cleaners and helpers \\
\hline 5241 & Fashion and other models & 911 & $\begin{array}{l}\text { Domestic, hotel and office cleaners and } \\
\text { helpers }\end{array}$ \\
\hline 5242 & Sales demonstrators & 9111 & Domestic cleaners and helpers \\
\hline
\end{tabular}


Appendix I (Continued)

\begin{tabular}{|c|c|c|c|}
\hline ISCO-08 & \begin{tabular}{|l|} 
Skilled service \\
(Oesch category I5)
\end{tabular} & ISCO-08 & \begin{tabular}{|l|} 
Low-skilled service \\
(Oesch category 16)
\end{tabular} \\
\hline 53 & Personal care workers & 9112 & $\begin{array}{l}\text { Cleaners and helpers in offices, hotels } \\
\text { and other establishments }\end{array}$ \\
\hline 531 & $\begin{array}{l}\text { Child care workers and teachers' } \\
\text { aides }\end{array}$ & 912 & $\begin{array}{l}\text { Vehicle, window, laundry and other } \\
\text { hand cleaning workers }\end{array}$ \\
\hline 5311 & Child care workers & 9121 & Hand launderers and pressers \\
\hline 5312 & Teachers' aides & 9122 & Vehicle cleaners \\
\hline 532 & $\begin{array}{l}\text { Personal care workers in health } \\
\text { services }\end{array}$ & 9123 & Window cleaners \\
\hline 5321 & Health care assistants & 9129 & Other cleaning workers \\
\hline 54 & Protective services workers & 94 & Food preparation assistants \\
\hline 541 & Protective services workers & 941 & Food preparation assistants \\
\hline 5411 & Fire-fighters & 9411 & Fast food preparers \\
\hline 5412 & Police officers & 9412 & Kitchen helpers \\
\hline 5413 & Prison guards & 95 & $\begin{array}{l}\text { Street and related sales and service } \\
\text { workers }\end{array}$ \\
\hline 5419 & $\begin{array}{l}\text { Protective services workers not } \\
\text { elsewhere classified }\end{array}$ & 951 & Street and related service workers \\
\hline \multirow[t]{3}{*}{8331} & Bus and tram drivers & 9510 & Street and related service workers \\
\hline & & 952 & Street vendors (excluding food) \\
\hline & & 9520 & Street vendors (excluding food) \\
\hline
\end{tabular}


Appendix 2 Full multinomial regression models la and Ib (OR)

Reference category: no effect.

\begin{tabular}{|c|c|c|c|c|c|c|c|c|}
\hline & \multicolumn{4}{|c|}{ Getting a job } & \multicolumn{4}{|c|}{ Getting a higher salary } \\
\hline & Coef. & p-value & \multicolumn{2}{|c|}{$\begin{array}{l}95 \% \text { conf. } \\
\text { interval }\end{array}$} & Coef. & p-value & \multicolumn{2}{|c|}{$\begin{array}{l}\text { 95\% conf. } \\
\text { interval }\end{array}$} \\
\hline Female (ref. male) & -0.091 & 0.545 & -0.384 & 0.203 & -0.580 & 0.003 & -0.967 & -0.193 \\
\hline $\begin{array}{l}\text { Service sector } \\
\text { (ref. Other) }\end{array}$ & 0.020 & 0.901 & -0.299 & 0.340 & -0.040 & 0.861 & $-0.49 \mid$ & 0.411 \\
\hline Mirror time (min) & 0.017 & 0.001 & 0.007 & 0.027 & 0.005 & 0.417 & -0.008 & 0.018 \\
\hline \multicolumn{9}{|c|}{ Education (ref. Primary) } \\
\hline Secondary & -0.465 & 0.022 & -0.862 & -0.067 & -0.314 & 0.236 & -0.833 & 0.205 \\
\hline Bachelor or higher & -0.444 & 0.022 & -0.822 & -0.065 & $-0.87 \mid$ & 0.001 & -1.376 & -0.365 \\
\hline $\begin{array}{l}\text { Countryside } \\
\text { (ref. Town) }\end{array}$ & -0.150 & 0.366 & -0.477 & 0.176 & -0.236 & 0.346 & -0.726 & 0.254 \\
\hline Age (years) & 0.010 & 0.018 & 0.002 & 0.019 & 0.014 & 0.026 & 0.002 & 0.026 \\
\hline Constant & -0.809 & 0.014 & -1.453 & -0.165 & -1.649 & 0.000 & -2.527 & -0.772 \\
\hline \multicolumn{9}{|l|}{ Negative } \\
\hline Female (ref.male) & 0.513 & 0.253 & -0.367 & 1.393 & -0.031 & 0.909 & -0.559 & 0.497 \\
\hline \multicolumn{9}{|l|}{ Service sector } \\
\hline (ref. Other) & -0.076 & 0.846 & -0.844 & 0.692 & 0.239 & 0.393 & -0.309 & 0.787 \\
\hline Mirror time (min) & -0.020 & 0.370 & -0.063 & 0.023 & 0.002 & 0.759 & -0.013 & 0.018 \\
\hline \multicolumn{9}{|c|}{ Education (ref. Primary) } \\
\hline Secondary & -0.554 & 0.482 & -2.099 & 0.991 & -1.407 & 0.000 & -2.185 & -0.630 \\
\hline Bachelor or higher & -1.612 & 0.044 & -3.177 & -0.046 & -1.827 & 0.000 & -2.685 & -0.968 \\
\hline $\begin{array}{l}\text { Countryside } \\
\text { (ref. Town) }\end{array}$ & 0.474 & 0.247 & -0.329 & 1.277 & -0.089 & 0.762 & -0.662 & 0.485 \\
\hline Age (years) & -0.041 & 0.014 & -0.073 & -0.008 & -0.017 & 0.112 & -0.038 & 0.004 \\
\hline Constant & -0.250 & 0.856 & -2.948 & 2.449 & $-0.49 \mid$ & 0.539 & -2.058 & 1.077 \\
\hline \multicolumn{9}{|c|}{ Both positive and negative } \\
\hline Female (ref.male) & -0.148 & 0.629 & -0.747 & 0.451 & -0.426 & 0.272 & -1.184 & 0.333 \\
\hline $\begin{array}{l}\text { Service sector } \\
\text { (ref. Other) }\end{array}$ & -0.399 & 0.247 & -1.076 & 0.277 & -0.289 & 0.449 & -1.035 & 0.458 \\
\hline Mirror time (min) & 0.009 & 0.379 & -0.011 & 0.029 & 0.003 & 0.858 & -0.029 & 0.035 \\
\hline \multicolumn{9}{|c|}{ Education (ref. Primary) } \\
\hline Secondary & -0.250 & 0.487 & -0.954 & 0.455 & -0.009 & 0.981 & -0.731 & 0.714 \\
\hline Bachelor or higher & -1.111 & 0.005 & -1.889 & -0.332 & -0.907 & 0.041 & -1.778 & -0.036 \\
\hline $\begin{array}{l}\text { Countryside } \\
\text { (ref. Town) }\end{array}$ & -0.388 & 0.282 & -1.095 & 0.319 & -0.153 & 0.675 & -0.867 & 0.562 \\
\hline Age (years) & -0.005 & 0.606 & -0.023 & 0.014 & 0.012 & 0.277 & -0.010 & 0.035 \\
\hline Constant & -1.633 & 0.014 & -2.937 & -0.329 & -3.049 & 0.000 & -4.703 & -1.395 \\
\hline $\mathrm{N}$ & 1356 & & & & 1356 & & & \\
\hline Pseudo-R2 & 0.028 & & & & 0.040 & & & \\
\hline
\end{tabular}


Appendix 3a Full multinomial regression models $2 \mathrm{a}(\mathrm{OR})$ for men and women Reference category: no effect.

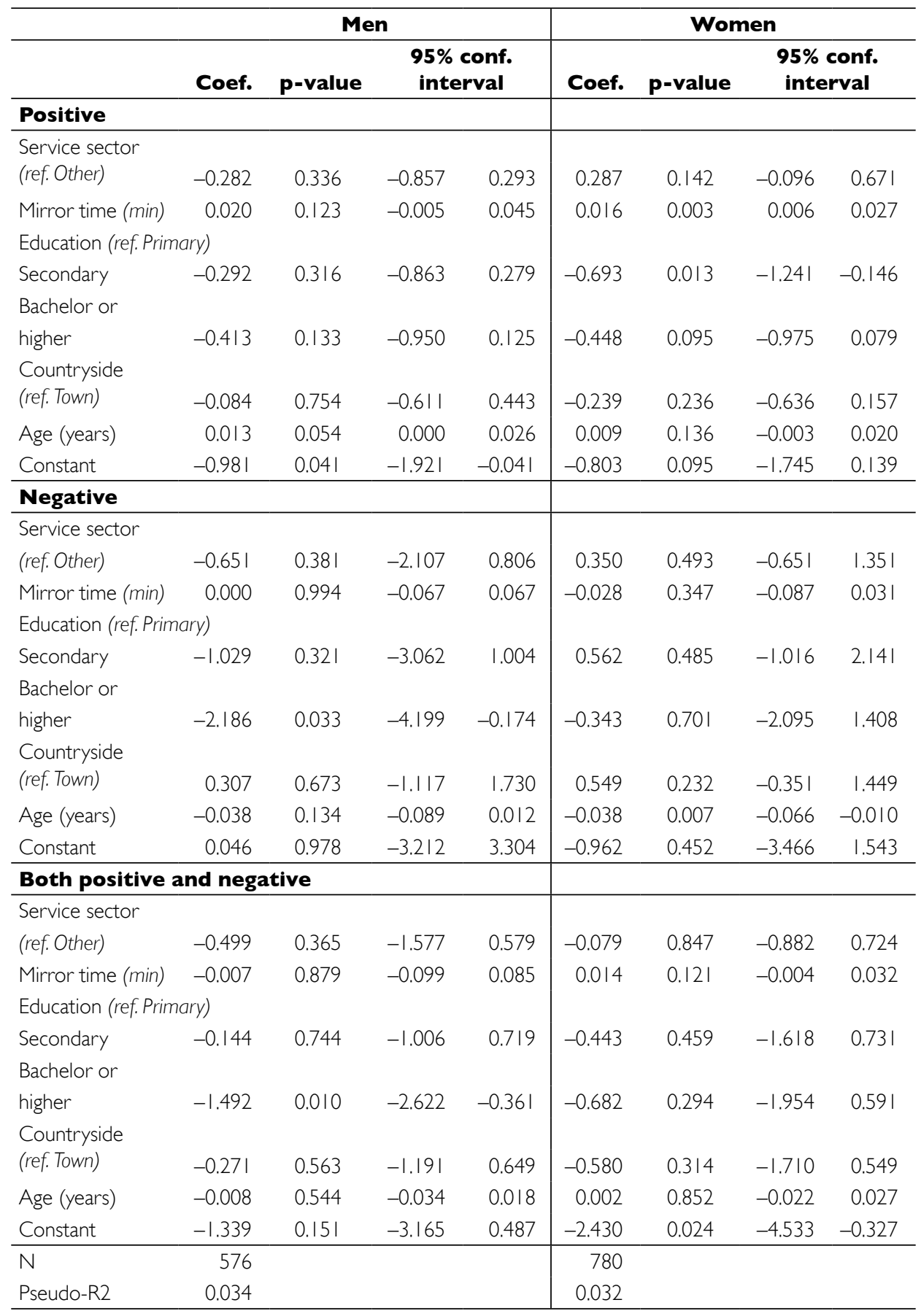


Appendix 3b Full multinomial regression models $2 b(\mathrm{OR})$ for men and women Reference category: no effect.

\begin{tabular}{|c|c|c|c|c|c|c|c|c|}
\hline \multirow{2}{*}{$\begin{array}{l} \\
\text { Positive }\end{array}$} & \multicolumn{4}{|c|}{ Men } & \multicolumn{4}{|c|}{ Women } \\
\hline & Coef. & p-value & \multicolumn{2}{|c|}{$\begin{array}{l}95 \% \text { conf. } \\
\text { interval }\end{array}$} & Coef. & p-value & \multicolumn{2}{|c|}{$\begin{array}{l}95 \% \text { conf. } \\
\text { interval }\end{array}$} \\
\hline $\begin{array}{l}\text { Service sector } \\
\text { (ref. Other) }\end{array}$ & -0.363 & 0.329 & $-1.09 \mid$ & 0.365 & 0.315 & 0.289 & -0.267 & 0.897 \\
\hline Mirror time (min) & 0.002 & 0.932 & -0.036 & 0.039 & 0.009 & 0.186 & -0.004 & 0.023 \\
\hline \multicolumn{9}{|c|}{ Education (ref. Primary) } \\
\hline Secondary & 0.040 & 0.913 & -0.673 & 0.753 & -0.999 & 0.006 & -1.719 & -0.280 \\
\hline Bachelor or higher & -0.609 & 0.084 & -1.300 & 0.081 & -1.232 & 0.001 & -1.945 & -0.519 \\
\hline $\begin{array}{l}\text { Countryside } \\
\text { (ref. Town) }\end{array}$ & -0.143 & 0.676 & -0.812 & 0.526 & -0.440 & 0.203 & -1.117 & 0.237 \\
\hline Age (years) & 0.012 & 0.150 & -0.004 & 0.027 & 0.017 & 0.072 & -0.002 & 0.036 \\
\hline Constant & -1.737 & 0.005 & -2.948 & -0.525 & -2.174 & 0.003 & -3.617 & -0.732 \\
\hline \multicolumn{9}{|l|}{ Negative } \\
\hline $\begin{array}{l}\text { Service sector } \\
\text { (ref. Other) }\end{array}$ & -0.899 & 0.123 & -2.039 & 0.242 & 0.818 & 0.051 & -0.003 & 1.638 \\
\hline Mirror time (min) & 0.003 & 0.891 & -0.042 & 0.048 & 0.001 & 0.866 & -0.015 & 0.018 \\
\hline \multicolumn{9}{|c|}{ Education (ref. Primary) } \\
\hline Secondary & -1.748 & 0.004 & -2.934 & $-0.56 \mid$ & -1.219 & 0.005 & -2.070 & -0.369 \\
\hline Bachelor or higher & -1.897 & 0.002 & -3.074 & -0.721 & -1.648 & 0.001 & -2.663 & -0.633 \\
\hline $\begin{array}{l}\text { Countryside } \\
\text { (ref. Town) }\end{array}$ & -1.187 & 0.020 & -2.189 & -0.185 & 0.559 & 0.110 & -0.127 & 1.245 \\
\hline Age (years) & -0.012 & 0.482 & -0.045 & 0.021 & -0.019 & 0.095 & -0.041 & 0.003 \\
\hline Constant & -0.280 & 0.798 & -2.426 & 1.867 & -0.992 & 0.266 & -2.741 & 0.757 \\
\hline \multicolumn{9}{|c|}{ Both positive and negative } \\
\hline $\begin{array}{l}\text { Service sector } \\
\text { (ref. Other) }\end{array}$ & -0.585 & 0.372 & -1.870 & 0.699 & -0.024 & 0.960 & -0.934 & 0.887 \\
\hline Mirror time (min) & 0.008 & 0.780 & -0.050 & 0.067 & 0.006 & $0.77 \mid$ & -0.033 & 0.045 \\
\hline \multicolumn{9}{|c|}{ Education (ref. Primary) } \\
\hline Secondary & 0.330 & 0.473 & $-0.57 \mid$ & 1.232 & -0.557 & 0.332 & -1.683 & 0.569 \\
\hline Bachelor or higher & -0.555 & 0.320 & $-1.65 \mid$ & 0.540 & -1.312 & 0.058 & -2.672 & 0.047 \\
\hline $\begin{array}{l}\text { Countryside } \\
\text { (ref. Town) }\end{array}$ & -0.178 & 0.712 & -1.124 & 0.768 & -0.076 & 0.888 & -1.134 & 0.982 \\
\hline Age (years) & 0.004 & 0.795 & -0.025 & 0.033 & 0.026 & 0.067 & -0.002 & 0.054 \\
\hline Constant & -2.902 & 0.004 & -4.892 & -0.911 & -3.975 & 0.003 & -6.562 & -1.387 \\
\hline $\mathrm{N}$ & 576 & & & & 780 & & & \\
\hline Pseudo-R2 & 0.038 & & & & 0.058 & & & \\
\hline
\end{tabular}

